\title{
The evolution of the concepts of growth, development and other related, during the last decades
}

\author{
LESZEK S. JANKIEWICZ
}

\begin{abstract}
Research Institute of Vegetable Crops, 22 Lipca 1/3, 96-100 Skierniewice, Poland
\end{abstract}
(Received: January 6, 1989. Accepted: February 22, 1989)

\begin{abstract}
The evolution of such terms as growth, differentiation, development, morphogenesis etc. is discussed. It is proposed that the term (notion) development should be understood to comprise "growth", "differentiation" and even "abscission, abortion and necrosis". The term "development" is already used in such a way by some authors. The relations among the phenomena denoted by the above terms are presented in a graphic form to show that they partly overlap. The concept that growth and development represent quantitative and qualitative aspects (respectively) of plant augmentation is criticized. The newly introduced terms "development hormone" or "development regulator" seem more suitable than "growth hormone" and "growth regulator". however, these later ones are correct and may be used. The traditional term "phytohormone" and the newly introduced one "phytoregulator" seem convenient, but it must be kept in mind that such substances may transmit information both on a chemical basis as well as on a biophysical one. An example here can be auxin; a change in the wavy character of its transport may serve as information. In some cases a complex of two or more substances may play the role of a hormone, for instance ACC and ethylene, of which one is easily transportable but little active and the other is very active but exerts its action rather locally. Other combinations of activities may exist in other such pairs.
\end{abstract}

Key words: nomenclature of growth and development, differentiation, ontogenesis, morphogenesis, photomorphogenesis, gravimorphism, growth hormone

Scientific nomenclature evolves in parallel to the development of our knowledge and it is natural that many concepts change their meaning gradually or even abruptly. The aim of the present paper is to consider the 
question if the nomenclature related to growth and develoment does not need some revision.

In the common language of many nations, the terms "growth" and "development" are used almost as synonyms. This probably reflects the fact that the plant body, when growing, usually becomes more and more complicated. These common language terms are usually not applied when one describes such phenomena like senescence, massive leaf abscission etc.

Scientists investigating the augmentation and complication of the plant body tried to determine more accurately the meaning of the mentioned terms and created new words such as differentiation, morphogenesis etc. Unfortunately this nomenclature was used arbitrarily which frequently led to confusion.

The term "growth" was used by Cronquist (1984) in a sense close to its common meaning. He speaks of "vegetative growth" and "floral growth" (this last term in the sense of reproductive development), "abnormal growth" in the case of plant galls etc. A large number of other authors consider "growth" as a purely quantitative aspect of plant augmentation. Dostál (1962) says: "growth is an irreversible change of the volume or shape... germination and growth are complex biological processes in which the new living substance protoplasma is formed". Czihak et al. (1976) says: "growth is achieved by cell augmentation or by their multiplication or by these two phenomena simultaneously". Steward (1969) says: "therefore growth may be seen in terms of building of complex molecules and macromolecular structures of cells and organelles. In accomplishing all this, order is created out of disorder, free energy is increased, entropy is locally reduced".

When the term "growth" was restrained to the quantitative aspect of plant augmentation, a second word was lacking which would cover the qualitative aspect of this process. For this purpose Lysenko (1952) used the word "development", as did Bonner and Galston (1958) and many other authors. Lysenko says "Under development of a seed plant we understand the process of indispensable qualitative changes in cell content and in organ formation which the plant undergoes from the seed to the formation of new seeds". Stew ard (1969) says: "Whereas growth is often held to be increase of size or of substance, development denotes the changing pattern of organization as growth progresses".

Such use of the word "development" creates some difficulties: the term "differentiation" becomes little distinct from "development" and no word is available which covers both aspects of plant body augmentation: qualitative and quantitative. To avoid this difficulty Bonner and Galston (1958) and Steward (1969) frequently use the double term "growth and development". This is practiced by many scientists even now.

Another group of plant physiologists uses the term "growth" in a sense similar to that of Bonner and Galston (1958) and Steward (1969), but applies the term "differentiation" to denote qualitative aspects of plant body 
augmentation. They use the term "development" as a superior one covering both quantitative and qualitative aspects of plant body increase (compare Loomis 1953, Wareing and Phillips 1971 and Moore 1979). For instance Welch (1968) considers development as a process by which new complete individuals are formed, starting from the cells contributed by the progenitors, and includes growth as well as differentiation. A similar view is represented by Czihak et al. (1976).

Listowski (1970) goes even further: "Saying development I understand the changes in the organism occurring in the time and in the space which are revealed by changes in the weight and volume and by the changes in the degree and character of organism differentiation. These changes may have in some period of the life increasing character and in the other declining". Thus Lis towski includes even senescence and abscission into "development". Also Wareing and Phillips (1981) say that senescence may be seen as the phase of development leading to the decay of cells and to death.

Is it right to include senescence into development? I think it is. For instance the development of an annual plant like maize terminates by the formation of seeds. However, at the end of its life, almost the whole plant senesces and this is a purely developmental process: the senescence of vegetative parts is necessary to allow a large part of nutrients to be liberated and transported to the seeds (compare Wareing and Phillips 1981). Similarly, in many arborescent plants, massive senescence and abscission of leaves and roots is an intrinsic part of their annual cycle of development.

The term "development" in the meaning given to it by Welch (1968), Listowski (1970) or Wareing and Phillips (1981) is a synonym of "ontogenesis", at least when referring to the whole plant organism. Chaylakhyan (1958) writes: "ontogenesis means individual development". In his work of 1958 he even preferred to use the term "ontogenesis" in place of “development". Also Czihak et al. (1976), Dostál (1962) and Michniewicz (1985) consider ontogenesis to be a synonym of individual development of a plant organism. The word ontogenesis is frequently used as an antonym of phylogenesis. For this reason and for its origin (ontos $=$ the being and not its part) it seems awkward to apply the term "ontogenesis" to an organ like a leaf or root. In this case the terms "organ development" or "organogenesis" seem to be more correct.

The meaning of the terms "growth", "development" etc. and the relations among them were presented by Jankiewicz (1979) in the form of a model. In it, these terms have the same significance as suggested by Listowski (1970) and Wareing and Phillips (1981). This model with some modifications is presented in Fig. 1. "Development" is represented in it by the largest rectangle with rounded corners which reflects the superior character of this term. Inside are three smaller rectangles representing "growth", "differentiation" and "abscission, jointly with abortion and necrosis". These last three phenomena 
are preceded, as a rule, by senescence, and may be considered as the reverse of growth: when growth is "an irreversible augmentation of a plant body", abscission, abortion or necrosis are the "irreversible diminution" of it.

The rectangles: "growth" and "differentiation" partly overlap. This is to indicate that differentiation is effected during growth and is mainly the result of unequal growth in a quantitative, spacial or qualitative sense. An exmaple of the latter is the formation of phloem and xylem cells from the same cambial cells. There exist, however, examples of growth without differentiation: initial callus growth in wounds, callus-like growth in tissue culture (see Wareing and Phillips 1981). Differentiation without growth also takes place sometimes: sclerenchyma cell walls continue to grow thicker and become impregnated with lignin after elongation has already terminated.

The rectangle "abscission, abortion and necrosis" partly overlaps with the rectangles "growth" and "differentiation". This is to indicate that abscission and abortion frequently need some growth and differentiation to be accomplished. For instance in the separation stratum in an abscising organ, cell divisions occur frequently as does cell augmentation (see Sexton and Roberts 1982, Addicott 1982, Jankiewicz 1985).

There are several other aspects of the use of the above mentioned terms. Differentiation may occur at different levels: differentiation of organelles and macromolecular structures at the subcellular level, differentiation of the cells to form various tissues, differentiation of the whole plant into its organs and smaller parts at the macroscopic level (see Jankiewicz 1979 and Wareing and Phillips 1981).

The organism passes through several stages (periods) of its development: embryonic, juvenile; transitory, mature and senescent. During these stages they show specific morphological and physiological characters (for instance juvenile levaes versus mature ones in the eucalyptus etc.). These ontogenetic stages are the background for other developmental processes and events. For instance, differentiation takes place both in juvenile plants as well as in aged ones, but the quality of this process differs in both cases.

In polycarpic plants some developmental phenomena may recur in a cyclic form, e.g. autumnal leaf fall. This does not interfere with the fact that the plant as a whole passes normally through its juvenile period, maturity and senescence.

If we wish to be consistent, some of the common terms connected with growth and development should be replaced or at least parallelly used with new more adequate ones. Thus the term "growth hormone" may be replaced or concomitantly used with "development hormone" or "developmental hormone". The term "growth regulator" may be replaced by "development regulator". In this situation the old term "phytohormone" seems to be very convenient because it is short. Analogically the new term "phytoregulator" may be proposed to substitute "plant growth regulator". Although this last 
term is composed of a mixed Greek and Latin member, there are several similar words as "phytosociology" which are widely used.

Difficulties have appeared recently with the classification of particular compounds as plant hormones. Y ang (1980) admits that ethylene does not fit in the classical definition of a hormone: a compound which "is synthetized in one site and is transported to another site where it exerts its physiological effect. Due to its gaseous nature, ethylene exerts its physiological effect only at or near a site where it is synthesized" (Y ang 1980). However, Y ang indicates that ACC, the precursor of ethylene, "may be synthesized in one part of a plant, be readily transported, and exerts its effect in another part of a plant". Thus ACC and ethylene may jointly transmit information. Nevertheless ethylene in a closed system, like apple fruit surrounded by rather tight superficial tissues, spreading in the intercellular spaces may inform all cells that the process of ripening has started and causes the synchronization of their physiological state. On the other hand, ACC may not move but serve as a source of ethylene in situ, for instance in tissues exposed to stress.

A similar pair of substances which jointly transmit information is TRIA (triacontanol) and TRIM (Ries and Wert 1988). TRIA is almost insoluble in water so it is almost immobile in plants, nevertheless in plant tissues it elicits a second messenger of an unknown nature, easily soluble in water, called TRIM. It is easily transported in a plant and exerts a powerful growth stimulatory effect.

In the authors opinion, the existence of such pairs of substances as ACC and ethylene or TRIA and TRIM indicate that sometimes the transmittance of a message involves more than one substance (not taking into account the whole system which produces the first messenger, and the other which reads and responds to the second message).

Still another difficulty is posed by the fact that for a long time plant hormones were thought of, as being chemical messengers, whereas the recent works of Wodzicki and Zajączkowski (Wodzicki et al. 1979, Zajączk ow s$\mathrm{ki}$ et al. 1984) and their co-workers indicate that in the case of IAA not only the hormone molecules themselves bear important information but that waves of IAA polar transport, which are propagated faster than the molecules themselves also carry information. Thus the frequency of the waves, their amplitude and direction of propagation may serve as an additional source of information for cells (Zajączkowski et al. 1983).

The annual developmental cycle of a plant needs adjustment to the climatic cycle of the year, therefore during their evolution plants have developed mechanisms to do this, for instance, that of photoperiodism. Hence, there are receptors which perceive external stimuli as well as mechanisms which transform them into chemical or other messengers. Such messengers are recognized by the target cells of a plant, i.e. group of cells which are able to read or eventually to realize a given message (compare Osborn 1982). 
Frequently, the action of an external stimulus has to be repeated several times or has to be continued for some time in order to be effective. In such cases the existence of a counting mechanism or clock mechanism which counts individual stimuli or measures the duration of their action was postulated (Fig. 1). Their nature is unknown. Plant development must also be regulated in space. To achieve this, gravitropism, phototropism and other tropisms were developed in plants during their evolution.

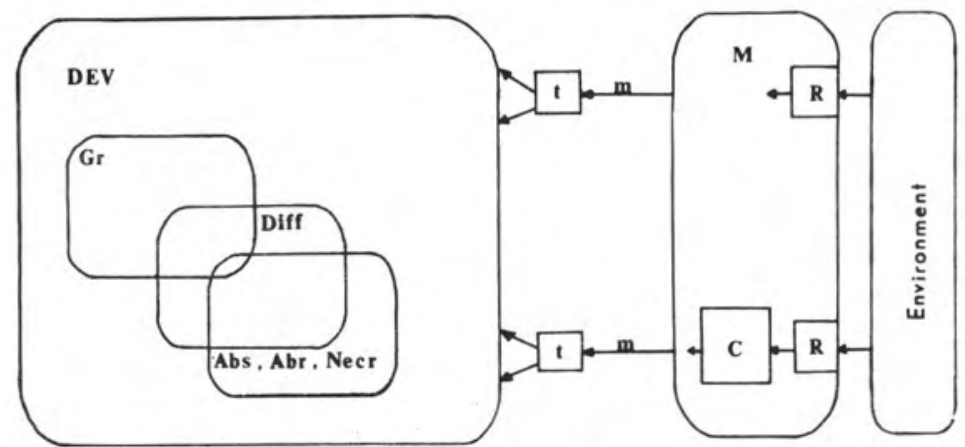

Fig. 1. Schematic presentation of the relations between different terms and phenomena: DEV - development; Gr - growth; Diff - differentiation; Abs, Abr, Necr - abscission, abortion, nercrosis (all three preceded by senescence): M - mechanism adjusting the development of an organism to the external conditions: the external stimuli are perceived by the receptors $(\mathrm{R})$ and are translated into messengers $(\mathrm{m})$ of chemical or physical nature, infuencing development. The messengers act mainly on the target cells $(\mathrm{t})$. Sometimes stimuli must act for some determined time to be perceived. This time is counted by a clock mechanism (C). The phenomena such as growth etc. take place during the different stages of development: embryonic, juvenile, transitory, mature and senescent. showing some specifity in each of them

Development may be investigated in different manners, one of them is detailed description, mainly quantitative (parametric description - see Bla u berg et al. 1973). Another is to systemize the observed developmental phenomena and to search for the relations among them and for their origin. This last field of investigation is usually included into morphogenesis. The direct meaning of this term is "origin of form" (Sin not 1960) and may be understood as an "assemblage of phenomena connected with the formation of a given shape of a plant" (Font-Quer 1982). Morphogenesis may also be considered as a branch of science devoted to elucidating the mechanisms responsible for the form of a plant. When one uses experimental methods in these investigations, the term "experimental morphogenesis" or "experimental morphology" or "analytical morphology" may be used (Sinnot 1960, von Denffer et al. 1967, Šebanek et al. 1983). Frequently, the authors do not use the term morphogenesis for such phenomena as senescence, abscission 
etc., however, it seems logical that, for instance, autumnal leaf abscission is a purely morphogenetic phenomenon since the form of a tree changes drastically.

Salisbury and Rose (1978) consider "morphogenesis" to be a synonym of what we (see Fig. 1) and several other authors call "development" (Listowski 1970, Wareing and Phillips 1971, 1981). In our opinion, "development" defines the changes which occur in the organism during the time-course of its life whereas the term "morphogenesis" emphasizes the mechanisms responsible for these changes (Wareing and Phillips 1981). The litter authors also indicate that form ("morphe" in Greek) may be understood in a wider sense - not only as ihe external shape of a plant but also as the organization of a plant body on different levels, including submicroscopic.

Concerning the other terms related to morphogenesis Czihak et al. (1976) says: "When the investigation is limited to the development of tissues we may say histogenesis, when to an organ - organogenesis, when to the embryo - embryogenesis etc.".

The external conditions frequently markedly influence morphogenesis: some of its aspects depend on light. temperature. gravity etc. In these cases the terms: photomorphogenesis, thermomorphogenesis and gravimorphism (or gravimorphogenesis) are used. It would be advisable to make this nomenclature more uniform. The terms "photomorphism", "gravimorphism" etc. are shorter than "photomorphogenesis" and "gravimorphogenesis" so they will probably win in the future. An example here is the term "gravimorphism" introduced by Wareing and his group. Probably nobody would like to replace it by gravimorphogenesis. In older botanical literature the terms "photomorphosis", "thermomorphosis" etc. also exist (Dostál 1962, Font-Quer 1982) which concern rather the final effect of the action of light, temperature etc. on the form of a plant. These terms are rather forgotten now.

\section{REFERENCES}

Addicott F. T., 1982. Abscission. Univ. California Press, Berkeley.

Blauberg I. W., Sadowski W. N., Judin E. G., 1973. Koncepcje systemowe we współczesnej nauce. In: Problemy metodologii badań systemowych. WNT, Warszawa (transl. from Rแwi:m)

Bonner I.. Gitlston A. W.. 1958. Principles of plant physiology. W. H. Freeman and Co.. San Francisco.

Chaylakhyan M. Kh., 1958. Osnovnie zakonomernosti ontogeneza vysshikh rastenii. Izd. Akad. Nauk SSSR, Moskva.

Cronquist A., 1984. Botanica basica. Editorial Continental, Mexico. (Transl. from English: Basic botany. Harper and Row Publ. 1973).

Czihak G., Langer H., Ziegler H. (eds.), 1976. Biologie. Springer, Berlin.

Ventter von, D., Mägdefrau K., Schumacher W., Fibras F., 1967. Lehrbuch der Botanik für Hochschulen, Gustav Fischer, Stuttgart. 
Dostál R., 1962. Fysiologie růstu, vývoje a pohybů. In: Zemědělská botanika. Dostál D.,

Dykyjová D. (eds.), Ceskoslovenská Akademie Zemědělských Věd, Praha.

Font-Quer P., 1982. Diccionario de botanica. $8^{\mathrm{a}}$ reimpresion. Editorial Labor, S. A. Barcelona.

Jankiewicz L. S., 1979. Regulacja procesów fizjologicznych w roślinie. In: Fizjologia roślin sadowniczych. Jankiewicz L. S. (ed.), PWN, Warszawa.

Jankiewicz L. S., 1985. Mechanism of abscission of leaves and reproductive parts of plants a model. Acta Soc. Bot. Pol. 54: 285-332.

Listowski A., 1970. O rozwoju roślin. PWRiL, Warszawa.

Loomis W. E., 1953. Growth and differentiation - an introduction and summary. In: Growth and differentiation in plants. Loomis W. E. (ed.), Iowa State Col. Press, Ames Iowa USA. Lvsenko T. D., 1952. Stadiynoe razvitie rastenii. Selkhozgiz, Moskva.

Michniewicz M., 1985. Fizjologia organizmu - wzrost i rozwój. In: Fizjologia roślin. Zurzycki J., Michniewicz M. (eds.), PWRiL, Warszawa.

Moore I. C., 1979. Biochemistry and physiology of plant hormones. Springer, New York.

Osborn D. J., 1982. The ethylene regulation of cell growth in specific target tissues of plants. In:

Plant growth substances 1982. Wareing P. F. (ed.), Academic Press, London.

Ries S. K., Wert V. F., 1988. Rapid elicitation of second messengers by nanomolecular doses of triacontanol and octacosanol. Planta 173: 79-87.

Salisbury F. B., Ross C. W., 1978. Plant physiology. Wadworth Publ. Co. Inc., Belmont California, USA.

Šebánek J., Sladký Z., Procházka S., 1983. Experimentálni morfologie rostlin. Academia, Praha.

Sexton R., Roberts J. A., 1982. Cell biology of abscission. Ann. Rev. Plant Physiol. 33: $133-162$

Sinnot E. W., 1960. Plant morphogenesis. McGraw-Hill, New York.

Steward F. C., 1969. Growth and development: the problems in perspective. In: Plant physiology, a treatise. F. C. Steward (ed.), vol. 5a, pp. XIX-XXXIV. Academic Press, New York.

Wareing P. F., Phillips I. D. J., 1971. The control of growth and differentiation in plants. Pergamon Press, Oxford.

Wareing P. F., Phillips I. D. J., 1981. Growth and differentiation in plants. Pergamon Press, Oxford (Polish transl.: Wzrost i różnicowanie się roślin. PWN, Warszawa, 1985).

Welch C. A., (ed.), 1968. Biological science, molecules to man. Houghton Mifflin Co., Boston (Spanish transl.: Ciencias biologicas. De las moleculas al hombre. Cia. Editorial Continental, Mexico D. F.).

Wodzicki T. J., Wodzicka A. B., Zajączkowski S., 1979. Hormonal modulation of the oscillatory system involved in polar transport of auxin. Physiol. Plant. 46: 97-100.

Yang S. F.. 1980. Regulation of ethylene biosynthesis. HortScience 15: 238-243.

Zajączkowski S., Wodzicki T. J., Bruinsma J., 1983. A possible mechanism for whole-nlant morphogenesis. Physiol. Plant. 57: 306-310.

Zajączkowski S., Wodzicki T. J., Romberger J. A., 1984. Auxin waves and piant morphogenesis. In: Hormonal regulation of development. II. T. K. Scott (ed.). Encyclopedia of plant physiology, New Series, Vol. 10, pp. 244-262. Springer, Berlin-Heidelberg.

Ewolucja terminów: wzrost, rozwój i pokrewnych w ciagu ostatnich dziesięcioleci

\section{Streszczenie}

Omówiono ewolucję terminów: wzrost, rozwój, dyferencjacja, morfogeneza i pokrewnych. Proponuje się, żeby pojęcie (termin) "rozwój” był używany jako nadrzędny obejmując "wzrost". dyferencjację i "zrzucanie organów oraz zamieranie". Takie znaczenie terminu "rozwój" jest już 
stosowane przez niektórych autorów. Zakresy zjawisk określonych powyższymi terminami przedstawiono w formie graficznej, aby wykazać, że częściowo nakładają się na siebie. Koncepcja, że wzrost i rozwój reprezentują odpowiednio ilościowy i jakościowy aspekt powiększania się ciała rośliny wydaje się dzisiaj trudny do przyjęcia. Sugeruje się, że nowo wprowadzone terminy "hormon rozwoju" i "regulator rozwoju" są lepsze, jako bardziej ogólne, niż "hormon wzrostu" i regulator wzrostu", jednak te dwa ostatnie są też poprawne i mogą być używane. Tradycyjny termin "fitohormon" i nowo wprowadzony "fitoregulator" wydają się także wygodne, z zastrzeżeniem, że uwzględni się rolę tych substancji jako przenośnika informacji nie tylko w sensie chemicznym, ale i w sensie biofizycznym; przenośnikiem informacji mogą być np. zmiany w falowym transporcie auksyn. W niektórych przypadkach rolę hormonu może grać zespół dwu lub więcej substancji, np. ACC i etylen, z których jedna jest łatwo transportowana, ale mało aktywna, a druga jest bardzo aktywna, ale wywiera działanie raczej lokalne. W innej takiej parze może istnieć inna kombinacja aktywności.

\section{Note}

Already when this paper was in press, the author received the book: M. Kh. Chailakhian, R. G. Butenko, O. N. Kulaeva, V. I. Kefeli and N. P. Aksenova, 1982. Terminologia rosta i razvitia vysshikh rasteniy. Izd. Nauka, Moskva, $96 \mathrm{pp}$. This bood presents the recent views of soviet plant physiologists on the terminology of growth and development and the book will be eventually reviewed in the next paper. 